\title{
ANTI-SEMITISMO NA EUROPA HOJE
}

\section{BILA SORJ}

\section{RESUMO}

O termo "anti-semitismo" é utilizado nas manifestações de hostilidade contra os judeus desde a Antiguidade. No entanto, como fenômeno histórico, o anti-semitismo é parte integrante das dinâmicas socioculturais e políticas de cada sociedade. Este artigo enfoca particularmente as especificidades que ele assume hoje na Europa Ocidental.

PALAVRAS-CHAVE: anti-semitismo; identidades comunitárias;

anti-sionismo.

\section{SUMMARY}

The term "anti-Semitism" is employed in manifestations of hostility against Jews since Antiquity. However, as a historical phenomenon, the anti-Semitism is part of the sociocultural dynamic and politics of each society. This article focuses particularly on its specificities in Western Europe today.

KEYWORDS: anti-Semitism; communitarian identities; anti-Zionism.

O termo "anti-semitismo" tem sido usado para designar, de forma genérica, as manifestações de hostilidade contra judeus desde os tempos greco-romanos até os dias de hoje.A longevidade e a persistência desse fenômeno social e a sua designação por meio de um único termo abrangente, "anti-semitismo", têm encorajado explicações de caráter a-histórico que empobrecem ou essencializam o fenômeno e suas interpretações, dificultando o entendimento de seus diferentes significados e formas de expressão em contextos societários específicos. 
O conteúdo universal e atemporal do termo "anti-semitismo" é reforçado no interior do judaísmo pela forma a partir da qual a identidade judaica se construiu desde os tempos bíblicos, através de uma narrativa que enfatiza a história de um pequeno povo, o povo de Israel, rodeado de inimigos que procuravam aniquilá-lo. Com a destruição do Segundo Templo pelos romanos no ano 70 d.C., que marca o fim do reino da Judéia e a transformação do povo judeu em um povo diaspórico, a narrativa se consolidou e permaneceu associada ao sentimento de insegurança de uma minoria condenada a constantes perseguições. Tal premissa forneceu aos judeus um sentido de destino comum compartilhado por gerações e fortaleceu os laços de solidariedade intragrupal entre as diversas diásporas.

A inclusão do anti-semitismo na cultura judaica, como uma constante universal' ${ }^{1}$, foi incentivada pelas elaborações teológicas do catolicismo e do islã, que justificaram, sob perspectivas diferentes, o destino trágico dos judeus já que rejeitavam aderir às novas revelações. $\bigcirc$ resultado foi que o anti-semitismo assumiu, nas várias religiões monoteístas, um estatuto, por assim dizer, teológico, isto é, um sistema de crenças que se auto-representa como eterno e, portanto, localizado fora da história.

Todavia, o anti-semitismo, como qualquer outro fenômeno histórico,é parte integrante das dinâmicas socioculturais e políticas específicas a cada sociedade, de tal forma que seus significados acompanham as transformações sociais e conferem novos sentidos às relações entre os judeus e a sociedade mais ampla. Porém, ao mesmo tempo, como veremos, as novas manifestações de anti-semitismo na Europa freqüentemente recolhem sua forma de expressão da retórica do antisemitismo clássico. Nesse sentido, procuraremos mostrar as continuidades e descontinuidades do fenômeno do anti-semitismo no mundo contemporâneo, focalizando particularmente as especificidades que ele assume hoje na Europa Ocidental.

\section{ANTI-SEMITISMO E MODERNIDADE}

Segundo Bauman², a animosidade em relação aos judeus na modernidade pode ser mais bem compreendida não como um sentimento de hostilidade em face do diferente ou daquilo que não é familiar (heterofobia), mas como um sentimento de desconforto perante aqueles que não se enquadram facilmente na estrutura de um mundo ordenado (proteofobia), que não podem ser claramente classificados nas categorias estabelecidas do "nós" e "eles". Esses seres ambivalentes, que emitem sinais contraditórios de conduta, acabam por expor as fragilidades e as fissuras da aspiração por um modelo ideal de vida social ordeira, previsível e sem riscos.

\begin{abstract}
[1] Para uma crítica à premissa do "eterno anti-semitismo", presente sobretudo entre muitos historiadores, ver Arendt, Hannah. Origens do totalitarismo $I-O$ anti-semitismo, instrumento de poder. Rio de Janeiro: Editora Documentário, 1979 [1973].
\end{abstract}

[2] Bauman, Zigmunt. Life in fragments: essays in postmodern morality. Oxford: Blackwell, 1995 [1988]. 
[3] Entre essas elites se destacam os fundadores do movimento sionista, que propunham a normalização do povo judeu mediante a construção de um Estado nacional e as instituições filantrópicas dedicadas a alterar a estrutura ocupacional dos judeus. Para uma análise dos empreendimentos filantrópicos no Brasil, ver Sorj, Bila. “'Normalizando' o povo judeu: a experiência da Jewish Colonization Association no Brasil". In:Identidades judaicas no Brasil contemporâneo. Rio de Janeiro: Imago, 1997.

[4] Apud Bauman, op.cit., p. 219.
A ordem na Europa moderna foi construída, segundo esse autor, pelo Estado-nação, e seu poder político se legitimou na produção de uma identidade coletiva que rejeitava costumes regionais, dialetos locais e minorias étnicas. Em uma Europa assim concebida, de nações, Estados e Estados-nações, os judeus eram praticamenteo único grupo que não se enquadrava nesse modelo. Não formavam uma minoria étnica própria a cada Estado nacional, uma vez que estavam espalhados por toda a Europa; tampouco eram residentes locais de uma nação vizinha, situação comum na Europa de fronteiras cambiantes daquele momento. Eram, de fato, percebidos como símbolo da incongruência: uma nação não-nacional que lançava uma nódoa na perfeição almejada pelos projetos nacionais. A imagem dos judeus como os "fora de lugar" foi além da questão das fronteiras nacionais e forneceu a chave para as percepções, então correntes, a respeito do lugar social dos judeus nas sociedades européias, inclusive entre as novas elites judaicas secularizadas 3. Em 1882, Leo Pinsker, um médico judeu na Rússia e precursor do sionismo, sintetizou as diferentes miragens em circulação na Europa: "para os vivos o judeu éum morto; para os nativos, um estranho e vagabundo; para os pobres e explorados, um milionário; para os patriotas, alguém sem pátria; para todas as classes, um concorrente odioso"4. O anti-semitismo europeu foi então produto de uma luta contra a ambivalência encarnada pelos judeus, que já entraram na modernidade carregando consigo a marca do "eterno judeu", construída pelo cristianismo no afã de diferenciar a nova religião da sua fonte original, ou seja, o judaísmo. Integrados, mas forasteiros; iguais, mas diferentes; admirados, mas assustadores.

\section{O ANTI-SEMITISMO CONTEMPORÂNEO NA EUROPA}

Nas sociedades européias atuais, caracterizadas por boa parte da bibliografia como pós-modernas, as identidades coletivas criadas pelos Estados nacionais já não apresentam a mesma capacidade normativa de conferir sentido e cristalizar o pertencimento dos indivíduos a uma comunidade de destino. Simultaneamente, surge uma profusão de identidades coletivas baseadas em laços religiosos, étnicos, diaspóricos e de caráter transnacional. Tais desenvolvimentos poderiam, em princípio, sugerir que os preconceitos e as hostilidades contra os judeus estariam desaparecendo, uma vez que a percepção sobre uma possível "dupla lealdade" ao Estado nacional já não constituiria mais a força motriz do anti-semitismo.

Não obstante, a Europa vem assistindo, desde o início do século XXI, a uma onda de manifestações antijudaicas impulsionada pelo conflito entre Israel e os palestinos 5 . O entendimento desse fenômeno, tratado pelos estudiosos como um "novo anti-semitismo", é muitas vezes 
afetado pela carga emotiva, ideológica e política que envolve o debate. Duas visões, igualmente extremadas, mostram-se insatisfatórias: aquela que minimiza o fenômeno, atribuindo-lhe caráter meramente episódico e inconseqüente, que decorreria dos confrontos legítimos no contexto do conflito israelo-palestino, e a que superdimensiona o enraizamento do anti-semitismo ao estabelecer relação de simples continuidade com o passado, atualizando a narrativa do "eterno anti-semitismo". Trivializações e excessos à parte, o fato é que nos últimos anos o problema do anti-semitismo entrou no debate público europeu mobilizando governos de diferentes países, organizações internacionais, institutos de pesquisa, organizações não-governamentais, academia e estimulando um amplo debate sobre o que passou a ser conceituado como "novo anti-semitismo".

Podemos identificar na atualidade manifestações antijudaicas em dois registros que, embora distintos, é provável que se alimentam mutuamente. $O$ primeiro diz respeito à utilização dos repertórios clássicos, típicos do anti-semitismo moderno, para se referir em especial a Israel e aos judeus, no contexto do conflito no Oriente Médio. Tais manifestações verbais, que serão precisadas mais adiante, podem ser encontradas nos meios universitários, por vezes na imprensa e na televisão, nos insultos e nas intimidações proferidos por alunos nas escolas, em grafites espalhados nas periferias das grandes cidades européias, nas manifestações dos movimentos antiglobalização e em sermões proferidos em algumas mesquitas do Continente. Provêm, assim, de espaços sociais e políticos notadamente distintos daqueles tributários do anti-semitismo tradicional, como partidos e organizações de extrema-direita, elites tradicionais e segmentos do clero e de camponeses.

O segundo se refere à escalada de atentados violentos contra judeus, ou pessoas assim consideradas, e suas instituições comunitárias. Apesar das dificuldades de registrar dados precisos sobre o volume dessas ocorrências, pela própria natureza dos atos em questão, os dados oficiais indicam um intenso crescimento de sua presença no espaço europeu desde $2000^{6}$.

Sinagogas foram cobertas de slogans racistas e danificadas com explosivos e bombas incendiárias; cemitérios judeus e memórias do Holocausto foram profanados; escolas judaicas foram pilhadas e incendiadas. O incidente mais grave ocorreu na Turquia em novembro de 2003 , país-membro do Conselho da Europa, quando duas sinagogas foram atacadas com bombas, provocando 24 mortes e deixando pelo menos trezentos feridos.

Os exemplos são abundantes ${ }^{7}$. A França, que abriga a maior comunidade judaica da Europa Ocidental (aproximadamente $500 \mathrm{mil}$ judeus) destacou-se por exibir no período os mais altos níveis de vio-
[6] Para um levantamento dos incidentes anti-semitas na Europa nos últimos anos, ver McClintock, Michel \& Sunderland, Judith.L'Antisémitisme en Europe: um défi à la indefférence officielle. Human Rights First, 2004 (www.HumanRightsFirst.org).

[7] Essas ocorrências estão detalhadas no relatório de Michel Posner, diretor executivo do Human Rights First apresentado ao State Committee on Foreign Relations dos Estados Unidos em abril de 2004 (www.humanrightsfirst.org/discrimination/antisemitism/Antisem_test_final4.pdf). 
[8] Estamos excluindo de nossa análise o anti-semitismo da extremadireita, uma vez que não é sobre essas manifestações que o debate público atual se concentra.

[9] Vários encontros governamentais foram realizados nos últimos anos para lidar explicitamente com esse problema. O mais recente foi a Conferência sobre Anti-Semitismo e outras Formas de Intolerância, em Córdoba, Espanha, em junho de 2005. lência. Pelo menos duas sinagogas foram incendiadas em 2003. Em março de 2004, um coquetel molotov foi lançado contra o centro comunitário de Toulon, que abriga duas sinagogas. Escolas judaicas também foram alvo de ataques. Um incêndio criminoso contra uma escola judaica em Gagny, na periferia parisiense, destruiu boa parte do edifício em novembro de 2003. Em outubro de 2003, o rabino Michel Serfaty foi atacado quando chegava com seu filho à sinagoga de Ris-Orangis, uma pequena cidade perto de Paris. Um grupo dentro de um automóvel lançou insultos racistas e ameaças evocando os conflitos do Oriente Médio. Outros ataques foram contidos a tempo pela polícia. Na Bélgica, uma creche comunitária foi pilhada e profanada na cidade de Uccle, em julho de 2003. Um mês antes, um homem tentou explodir um automóvel cheio de garrafas com gás em frente a uma sinagoga em Charleroi; um ano antes, tiros de metralhadora foram disparados contra outra sinagoga na mesma cidade. NaAlemanha,em setembrode 2003 , a polícia deteve suspeitos para evitar uma tentativa de atentado à bomba previsto para ocorrer em 9 de novembro, data do aniversário do pogrom conhecido como a "Noite de Cristal", que marcou a perseguição sistemática aos judeu-alemães pelo regime nazista. $\mathrm{O}$ atentado estava previsto para acontecer durante a cerimônia de lançamento da pedra fundamental de uma sinagoga no centro de Munique, da qual participariam centenas de judeus e de políticos. Judeus e estabelecimentos judaicos também foram alvo de ataques na Rússia e em outros lugares da antiga União Soviética: uma granada foi lançada contra a sinagoga em Derbent em janeiro de 2004, três coquetéis molotov contra uma sinagoga em Chelyabinsko em fevereiro de 2004, e menos de dois meses depois uma sinagoga em Nizhny Novgorod foi atacada. Tentativas de incêndio foram reportadas em sinagogas de Minsk, na República de Belarus (ex-Bielo-Rússia), em agosto de 2003.A fachada do edifício foi danificada nesta que foi a quinta tentativa de incêndio em dois anos. Registraram-se incidentes semelhantes nos demais países europeus, notadamente na Grã-Bretanha e na Holanda.

Esses dois registros, da retórica e das agressões físicas dirigidas contra os judeus, não configuram um movimento coerente e articulado. Apresentam, contudo, algumas características comuns a partir das quais o anti-semitismo corrente assume uma nova configuração, sobretudo na Europa Ocidentals.

A primeira característica diz respeito ao fato de o anti-semitismo atual, diferentemente do período que antecede a Segunda Guerra Mundial, e em contraste com o dos países do antigo bloco soviético no período pós-guerra, encontrar-se sobretudo na sociedade e não no Estado. Praticamente em todos os países da Europa as autoridades estatais rejeitam explicitamente o anti-semitismo e implementam leis e políticas que visam combatê-lo9. 
Com relação ao grau de penetração de idéias anti-semitas na população da Europa, as indicações disponíveis são contraditórias. Não faltam evidências a indicar que os judeus hoje se encontram bem integrados nas sociedades européias e que não enfrentam obstáculos ao desenvolvimento de suas vidas pessoais e comunitárias. Muitos países celebram seus judeus e sua cultura: proliferam museus, antigas sinagogas são restauradas, cursos de iídiche são oferecidos em estabelecimentos de educação para adultos, e música e culinária judaicas adquirem grande popularidade.

Em contrapartida, informações obtidas por meio de pesquisas de opinião destinadas a mensurar o nível de difusão dos preconceitos antijudaicos chegam a conclusões divergentes da apreciação anterior. Pesquisa recente realizada em doze países europeus pela Anti-Defamation League e publicada em $2005^{10}$ mostra a força de afirmações estereotipadas: "os judeus são mais leais a Israel do que a este país" obteve a concordância de $43 \%$ dos entrevistados, "os judeus têm muito poder no mundo dos negócios" contou com a concordância de $30 \%$, "os judeus têm muito poder no mercado financeiro internacional" obteve $32 \%$ de concordância e $42 \%$ consideraram como provavelmente correta a proposição "os judeus ainda falam muito sobre o que lhes aconteceu no Holocausto".

A segunda característica das recentes manifestações de hostilidade contra os judeus é que hoje não configuram, na maior parte dos casos, um movimento organizado de mobilização política, tal como ocorria no passado.As manifestações são difusas, pouco articuladas e os autores nem sempre se declaram anti-semitas. Essa situação contribui significativamente para tornar o "novo anti-semitismo" um conceito contestado. Critérios que são vistos por alguns como centrais na definição do "novo anti-semitismo" - como, por exemplo, o anti-sionismo - são completamente rejeitados por outros. Tratando-se de um terreno que possui uma excepcional carga normativa e emotiva, abrese espaço para intensas disputas terminológicas e políticas sobre a tipificação desses eventos, como veremos adiante.

A terceira característica refere-se ao lugar central que o conflito no Oriente Médio assumiu na motivação das manifestações de animosidade contra os judeus ${ }^{11}$.A mudança da origem da animosidade - antes orientada para a condição estrutural dos judeus na Europa Ocidental e hoje para a condição de diáspora cultural e política de Israel - marca uma significativa diferença com o anti-semitismo moderno ${ }^{12}$. Como afirma Arendt ${ }^{13}$, a origem do anti-semitismo moderno decorreu da posição social dos judeus nas sociedades européias do século XVIII e XIX, particularmente da relação que se estabeleceu entre eles e os Estados nacionais em formação. Argumenta que, como os judeus estavam fora da estrutura de classes sociais estabelecidas, dependiam da prote-
[10] Os países pesquisados foram Áustria, Bélgica, Dinamarca, França, Itália, Alemanha, Holanda, Espanha, Suíça, Grã-Bretanha, Hungria e Polônia. A pesquisa mostra que a idade mais avançada e o menor nível de escolaridade são fatores-chave na probabilidade de os entrevistados concordarem com os estereótipos anti-semitas (Anti-Defamation League, Attitudes towards Jews in twelve European countries, maio 2005).
[11] Certamente, a extrema-direita européia continua a ver os judeus como agentes de uma modernidade incontrolável que ameaça as virtudes das sociedades nacionais fundadas na tradição.

[12] Emalguns países, o pico dos incidentes ocorreu durante o mês de abril de 2002, justamente no momento em que o exército israelense ocupou várias cidades palestinas, provocando acirrada controvérsia sobre a política de ocupação e os métodos utilizados para conter a Segunda Intifada.

[13] Arendt, op.cit. 
[14] Para um inventário que identifica os autores dos atentados, ver European Monitoring Centre on Racism and Xenophobia, Manifestations of anti-Semitism in the EU-20022003, 2005 (http://eucm.eu. int). O relatório alerta, todavia, para os limites dos dados coletados, uma vez que a maior parte das classificações dos autores dos ataques foi baseada apenas nas percepções das vítimas e de testemunhas. ção do Estado nacional, que, por sua vez, necessitava da elite financeira dos judeus para sustentar suas transações comerciais. A dependência recíproca, entre os judeus eo Estado, gerou uma noção exagerada a respeito do poder que os judeus detinham nessas sociedades. Em contraste, o anti-semitismo contemporâneo não se funda, de maneira geral, em uma concepção específica da condição socioeconômica dos judeus na estrutura das sociedades européias, mas na sua estreita ligação com Israel.

A quarta característica diz respeito aos responsáveis pelos atos de violência dirigidos contra os judeus e contra suas instituições comunitárias. Pesquisas revelam que boa parte dos autores de atentados não é militante de extrema-direita, mas "jovens mulçumanos", "pessoas de origem norte-africana" ou "imigrantes", notadamente na França, na Bélgica e na Grã-Bretanha ${ }^{14}$. Cabe destacar que, muitas vezes, o recurso a tais categorias amplas para caracterizar pessoas parece sustentar a hipótese da existência de comunidades homogêneas que compartilhariam certas características resultantes do seu contexto étnico ou religioso. A identificação dos autores como membros de "comunidades" pode levar, de modo geral, à atribuição de responsabilidades coletivas a atos individuais, produzindo a "islamofobia", fenômeno correlato ao anti-semitismo. Nesse sentido, é importante que se retenha a perspectiva de que "comunidades" apresentam diferenciações internas, não apenas no que diz respeito à sua inserção na estrutura socioeconômica, mas também na sua adesão a diferentes referências identitárias.

\section{ANTI-SEMITISMO: GLOBALIZAÇÃO E IDENTIDADES COMUNITÁRIAS}

Duas ordens de razões são freqüentemente apresentadas para explicar a associação entre os atos de animosidade verbal eos de violência física dirigidas aos judeus por indivíduos ligados a essas comunidades que, a meu ver, não são excludentes. A primeira diz respeito à transnacionalização dos conflitos do Oriente Médio. Jovens oriundos das comunidades de imigrantes de países árabes e muçulmanos na Europa teriam um forte sentimento de identificação com o destino dos palestinos. Tal identificação seria particularmente promovida por veículos de comunicação de alguns países árabes captados via satélite em território europeu, por sermões proferidos em algumas mesquitas por líderes radicais islâmicos, por discursos pronunciados por vários governantes de países árabes e muçulmanos. Esses discursos normalmente produzem uma fusão das categorias "judeus", "israelenses", "sionistas", "Estado de Israel", "políticas do governo de Israel", "comunidade judaica" e "religião judaica", transformando cada judeu individualmente - bem como as suas mais variadas instituições comunitárias - em alvo auto- 
mático da expressão de indignação com a situação do Oriente Médio. Assim, todo judeu é percebido como "representante" das imagens políticas que são elaboradas a respeito de "Israel".

A forte identificação de jovens descendentes de imigrantes oriundos notadamente do Norte da África com os palestinos pode ser entendida com base na emergência do que Olivier Roy ${ }^{15}$ denominou "islã globalizado". Segundo o autor, o islã vem se afirmando, tanto na sua versão pietista como nas suas formas mais radicais e políticas, como uma ummah (nação) globalizada, desconectada de um território e de uma cultura particular. Uma evidência da nova configuração é o crescente número de jovens descendentes de imigrantes do Norte da África e do mundo árabe que, no Ocidente, definem-se prioritariamente como de identidade muçulmana e não segundo o país ou a cultura de origem de seus pais. $O$ sucesso desse projeto religioso se deve à capacidade de oferecer alguma referência identitária que preencha o vazio deixado pela perda de raízes e da cultura herdada e pela frouxa identificação com a cultura dominante. A nova concepção do islã, segundo o autor, tem na internet um instrumento perfeito para fazer avançar o modelo de comunidade abstrata de crentes, desligados de qualquer cultura específica nacional.

Os judeus na França também mostram claros sinais de que sua identidade está em franca reestruturação. O modelo clássico de integração formulado no período da emancipação dos judeus após a Revolução Francesa, cujo mote era "tudo aos judeus como indivíduos e nada como nação", exibe claros sinais de desgaste ${ }^{16}$. Sob vários aspectos, é possível discernir o fortalecimento da identidade judaica de tipo "comunitarista". Indicação eloqüente nesse sentido consiste no quase desaparecimento do termo "israelita" como auto-identificação dos judeus e sua substituição pela designação "judeu”. O termo "israelita”, que alude a uma confissão a ser praticada na esfera da vida privada, foi adotado pelos judeus assimilados do século XIX, que assim pretendiam evitar o uso do termo "judeu" pelo que carregava de pejorativo. Hoje, a situação se inverteu. Os judeu-franceses passaram a se autoidentificar como "judeus" enquanto o termo "israelita" tornou-se quase pejorativo, justamente por aludir a um judeu envergonhado, que teria reprimido sua identidade em nome da assimilação.

Nas últimas duas décadas, a freqüência de crianças em escolas da comunidade aumentou. Com efeito, os judeus se mostram mais inclinados a participar da vida comunitária ${ }^{17}$. Ademais, começaram a se afirmar como atores visíveis no espaço público, bem como a expressar sua proximidade com Israel, que passou a ter um importante papel para aqueles judeus que reclamam para si uma identidade "étnica". À semelhança de outras comunidades que reivindicam alguma origem nacional anterior à imigração para as sociedades européias, os judeus
[15] Roy, Olivier. Globalised Islam. The search for a new ummah. Nova York: Columbia University Press, 2004.

[16] Cohen, Martine. "Les Juifs de France: modernité et identité". Revue d'Histoire, n. 66, abr.-jun. 2000. 
[18] Suzan, Bénédicte \& Dreyfus, JeanMarc. Muslims and Jews in France: communal conflits in a secular state. The Brookings Institution U.S.-France Analysis, Washington, 2004 (http:// www.brookings.edu/fp/ cusf/analysis/suzan2004 0229.pdf).

[19] Durkheim, Émile. "Antisémitisme et crise social". In: Victor Karady (org.), Textes, vol. 2 - Religion, morale, anomie. Paris: Éditions de Minuit, 1975. também teriam a sua nação originária, Israel. Não é a nação de onde efetivamente imigraram (no caso da França, os judeus são majoritariamente oriundos dos países do Norte da África), mas de uma nação mítica cujos laços são constantemente emulados pelo governo de Israel e por várias lideranças comunitárias, embora nem todos definam em Israel o foco da sua identidade e, menos ainda, mostrem-se inclinados a imigrar para aquele país.

Desse modo, acentua-seo processo de recomposição das identidades de árabes/muçulmanos e de judeus. No primeiro caso, em função do distanciamento de uma herança nacional e da adesão a uma comunidade religiosa transnacional; no segundo, em razão do enfraquecimento da identificação com o modelo republicano e do fortalecimento da identidade comunitária. Ambos os grupos passaram, então, a repercutir de maneira mais intensa os conflitos do Oriente Médio.

A segunda ordem de razões considera que a hostilidade contra os judeus na Europa não pode ser entendida apenas como conseqüência direta da transferência e da apropriação dos problemas políticos do Oriente Médio. Suzan e Dreyfus ${ }^{18}$ argumentam que a violência é sobretudo a expressão do descontentamento com as dificuldades que parcelas importantes de imigrantes árabes/muçulmanos e seus descendentes têm enfrentado na integração à sociedade francesa, particularmente no sistema educacional e no mercado de trabalho. Assim, o discurso antiocidental, antiisraelense e antijudeu permitiria a esses jovens expressar sua frustração e lhes daria uma nova filiação identitária.Analogamente, a reação dos judeus à violência se deveria menos ao conflito no Oriente Médio ou ao temor da comunidade mulçumana e mais ao medo do ressurgimento do anti-semitismo na população francesa em geral. Tratados sob essa ótica, os atos de hostilidade contra os judeus adquirem uma dimensão propriamente nacional, na qual estariam em jogo os antagonismos entre minorias e o próprio futuro da sociedade francesa. Mas, seé assim, a pergunta que se segue é: por que os judeus na Europa se tornaram o alvo privilegiado das manifestações de descontentamento de grupos de imigrantes árabes/mulçumanos e seus descendentes na Europa?

Alguns estudiosos adotam a velha noção de "bode expiatório" para explicar a animosidade contra os judeus. Segundo tal interpretação, o anti-semitismo emanaria de uma situação de crise ou de um episódio de frustração social intensa. Durkheim ${ }^{19}$ já havia proposto essa explicação em 1899, a propósito do caso Dreyfus, escândalo político que dividiu a França por muitos anos, provocado pela falsa condenação por traição de um oficial do Exército de origem judaica. O autor afirma que "quando a sociedade sofre, ela tem necessidade de encontrar alguém a quem imputar seu mal"2o. Para esse papel de bode expiatório seriam designados aqueles cuja imagem já carrega algum tipo de juízo nega- 
tivo da opinião pública. Interpretada por essa chave analítica, Rosenbaum ${ }^{21}$ considera que as dificuldades de inserção socioeconômica na sociedade mais ampla seriam vividas como frustrações de minorias que se projetam por meio da incriminação dos judeus ("eles controlam os meios de comunicação", "eles têm tudo, nós não temos nada").Uma vez que a maioria dos judeus descende de imigrantes do Norte da África, a animosidade se agrava pela facilidade de estabelecer comparação com os demais imigrantes da região, alimentando a inveja e a hipersensibilidade perante os destinos sociais dos grupos.

De fato, o processo de integração dos judeus na França foi bemsucedido e passou a simbolizar um modelo que parece inacessível a outras minorias, especialmente às de origem norte-africana. Em 2002, mais da metade dos domicílios de judeu-franceses situava-se na região parisiense; quase metade dos chefes de família tinha grau universitário, índice superior à média dos franceses ${ }^{22}$.

Todavia, a explicação a partir da categoria do "bode expiatório", que remete prioritariamente às desigualdades socioeconômicas entre "comunidades" e a processos de ordem psicológica, não atenta para o poder das imagens e representações construídas acerca da relação entre "Israel" e "os palestinos" sobre a formação identitária dos jovens imigrantes ou descendentes de imigrantes dos países árabes/muçulmanos.

Wieviorka23 assinala justamente a importância de levar em conta as duas dimensões do problema: a de "dentro" (condição de exclusão) ea de "fora" (o conflito entre Israel e os palestinos) para explicar a animosidade antijudaica. $\mathrm{O}$ autor conseguiu captar, no discurso dos seus entrevistados ${ }^{24}$, a correspondência mítica que jovens descentes de imigrantes do Norte da África estabelecem entre o mundo definido pelo viés palestino e a situação deles na França. Desse modo, os jovens sublinham

a impotência dos árabes no mundo (e a deles próprios na França), a incapacidade de os árabes e os mulçumanos se ajudarem (o que eles observam que também ocorre entre seus correligionários na França), a inaptidão dos países muçulmanos para socorrer os palestinos e, enfim, a hegemonia de um pequeno país, Israel, sobre o mundo muçulmano (do mesmo modo que o judeu imaginário imporia à França os interesses de uma pequena comunidade minoritária) 25.

A construção de uma retórica de vitimização, como observa Chaumont $^{26}$, marca a maneira pela qual, na atualidade, grupos excluídos se auto-representam e definem suas estratégias políticas para obter acesso privilegiado a recursos materiais e simbólicos. Visto por esse prisma, os conflitos entre minorias podem ser entendidos como uma disputa para ocupar o "campo social da vitimização". Como hipótese,
[21] Rosenbaum, Aléxis. L'Antisémitisme. Paris: Breal, 2006.

[22] Cohen, op.cit.

[23] Wieviorka, Michel. La tentation antisémite: haine des juifs dans la France d'aujourd 'hui. Paris: Lafont, 2005.

[24] A pesquisa foi realizada a partir de entrevistas com jovens muçulmanos encarcerados em presídios.

[25] Wieviorka, op.cit., p. 195.

[26] Chaumont,Jean-Michel.Laconcurrence des victimes: génocides, identité, reconnaissance. Paris: La Decouverte, 1997. 
[27] Foxman, Abraham H. Never again? The threat of the new anti-Semitism. Nova York: HarperCollins/HarperSan Francisco, 2003; Dershowitz, Alan. The case for Israel. Hoboken, New Jersey: John Wiley \& Sons, 2003; Chesler, Phyllis. The new antiSemitism: the current crisis and what we must do about it. San Francisco: Jossey-Bass, 2003.

[28] Sarfati, Georges-Elia. L'Antisionisme. Israël/Palestine aux miroirs d'Occident. Paris: Berg International, 2002.
[29] Para uma visão da diversidade atual de pontos de vista acerca do sionismo na elite intelectual, política e acadêmica de Israel, ver Flint, Guila \& Sorj, Bila.Israel, terra em transe. Democracia ou teocracia? Rio de Janeiro: Civilização Brasileira, 2000. o autor sugere que os excluídos de hoje não dispõem dos mesmos recursos que os explorados de ontem para negociar uma situação mais favorável no sistema, como, por exemplo, a ameaça de paralisação da produção por meio de greve. $\mathrm{Na}$ falta de outra moeda de troca, o recurso à posição de vítima passa a ser o único instrumento disponível para validar as reivindicações de grupos minoritários.

No ambiente de concorrência entre vítimas, os judeus e o Holocausto são percebidos como ocupando por muito tempo um amplo espaço e hostilizados pelas "novas vítimas", que os acusam de monopolizar a culpa coletiva local.Adisputa pelolugarde vítima muitas vezes resvala para a banalização do sofrimento do concorrente, quando não para a própria negação do Holocausto, como veremos a seguir.

\section{UM "NOVO ANTI-SEMITISMO"?}

A escalada de violência antijudaica nos últimos anos deu origem a um debate complexo e muitas vezes confuso sobre a presença de um "novo" anti-semitismo na Europa ${ }^{27}$. O anti-semitismo atual seria basicamente definido como oposição à existência do Estado de Israel, um Estado criado como resultado das atividades do movimento sionista entre 1897 e 1948, bem como da decisão das Nações Unidas em 1947. Segundo essa visão, os ataques à existência de Israel seriam manifestações inerentemente anti-semitas, pois recusam aos judeus o direito nacional à autodeterminação, isto é, o direito de decidir sobre sua própria vida comunitária, suas leis e suas regras, suas instituições, seus símbolos e seu destino político ${ }^{28}$. Em contraposição, outros consideram o anti-sionismo um discurso político legítimo, sem implicações xenofóbicas.Argumenta-se que, embora a maioria dos anti-semitas autodeclarados de hoje use a retórica anti-sionista, historicamente muitos anti-semitas eram pró-sionistas. De fato, na Alemanha e na Polônia, antes da Segunda Guerra Mundial, muitos políticos antisemitas apoiavam a emigração ou a expulsão dos judeus para a Palestina como forma de solucionar o "problema judaico". O anti-sionismo também marca presença entre correntes minoritárias de ultra-ortodoxos, em Israel e no exterior, que rejeitam o sionismo porque contrariaria a vontade divina de redenção messiânica; há também judeus seculares e de esquerda em Israel que se opõem à existência de Israel como um estado especificamente judeu e propõem que ele deveria ser substituído por um estado secular no qual judeus e árabes teriam os mesmo direitos; outros ainda consideram que a criação do Estado de Israel não teria sido a melhor solução para as dificuldades que os judeus enfrentavam na diáspora, mas, uma vez que ele existe, não é possível voltar ao status quo anterior ${ }^{29}$. Assim, a visão crítica do sionismo não é alheia à própria história interna do judaísmo. Entretanto, 
ao contrário de vários outros movimentos políticos, religiosos e de governos, particularmente nos países árabes ou muçulmanos, esses grupos recusam a utilização da força para transformar a realidade atual. Em princípio, pode-se dizer que anti-semitismo e anti-sionismo não são sinônimos. Se, para alguns, tratá-los como conceitos equivalentes seria apenas uma estratégia defensiva para inibir as críticas às políticas do Estado de Israel ${ }^{30}$; para outros, insistir na separação radical entre eles dificultaria a apreensão dos preconceitos antijudaicos que se dissimulam no discurso anti-sionista.

Diante da acirrada disputa sobre a relação entre críticas a Israel e anti-semitismo, o European Monitoring Centre on Racism and Xenophobia ${ }^{31}$ elaborou uma definição de anti-semitismo de caráter operacional, que permitiria separar o anti-sionismo como um preconceito baseado em visão estereotipada do "judeu" e aquele cujo sentido é baseado em uma causa política que pode não ser, em si mesma, antijudaica. Assim, considera-se anti-semitismo "qualquer ato ou atitude que se baseia na percepção de um sujeito social (individual, grupo,instituição ou país)" como "o (enganoso, corrupto, conspiratório etc.) judeu"32. Em outras palavras, o anti-semitismo ocorre quando judeus são percebidos e tratados segundo atributos típicos do judeu imaginário, construído por meio de categorias estereotipadas. No que diz respeito a Israel - incluindo-se aí tanto as posições contra a existência do Estado como aquelas que criticam as políticas do governo -, considerou-se que quando é percebido como representante do "judeu", istoé, como representante dos traços construídos pelo anti-semitismo acerca dos judeus, tais manifestações seriam claramente consideradas expressões de anti-semitismo.

No debate público atual as fronteiras entre esses dois planos muitas vezes se confundem, pois a utilização da retórica e de imagens típicas do anti-semitismo clássico para criticar o Estado de Israel é freqüentemente acionada. Passaremos a identificar algumas manifestações retóricas do anti-sionismo que, a meu ver, configuram a confluência entre anti-sionismo e anti-semitismo.

\section{ANTI-ISRAEL E ANTI-SEMITISMO}

Caso típico de crítica a Israel, que pode ser interpretada como ativadora de preconceitos antijudaicos, expressa-se nas acusações dirigidas à instituição "lobby pró-Israel”, em Washington, que exerceria um poder conspiratório e manipulador da política externa norte-americana. $O$ caráter preconceituoso associado a essa instituição, muitas vezes chamada de "lobby judeu", residiria menos no reconhecimento de sua força, o que aliás é publicamente reconhecida pela sua liderança 33, e mais nos tipos de acusação a ela imputadas, tais como de
[30] Finkelstein, Norman. Beyond chutzpah: on the misuse of anti-Semitism and the abuse of history. Califórnia: University of California Press, 2005.

[31] Instituição criada pela União Européia para monitorar as manifestações de racismo e anti-semitismo no Continente. VerManifestations of antiSemitism in the EU-2002-2003, cit.

[32] Ibidem, p.13.

[33] The American Israel Public Affairs Committee (AIPAC) é um dos mais importantes lobbies americanos. Em seu site, a seção "quem somos" traz explicitamente esse reconhecimento. A organização assim se apresenta: "Por essas razões, o The New York Times chamou o AIPAC a mais importante organização que afeta a relação entre os Estados Unidos e Israel, enquanto a revista Fortune sistematicamente classifica o AIPAC entre os mais poderosos grupos de interesse da América" (http://www. aipac.org/about/). 
"dupla lealdade" de seus ativistas, de "agir contra os interesses americanos" e de "controlaro governo americano". Essas incriminações são, com efeito, apropriadas à retórica anti-semita tradicional que aciona a figura imaginária do "judeu”" não importa ondeestejam, os judeus formam um Estado dentro do Estado, aprisionando a sociedade no interior da qual vivem. Provavelmente, esse é um dos únicos lobbies norteamericanos cujos críticos, não todos evidentemente, acionam uma linguagem desse tipo. Outros lobbies, apesar de muito criticados, não são alvo da mesma retórica. Como exemplo, a crítica ao dos latinos anticastristas, igualmente ativo e bem-sucedido, não se vale do mesmo tipo de condenação moral, nem mesmo pelos simpatizantes da Revolução Cubana. Interessante notar que a nova construção moral da categoria "lobby pró-Israel" foi acompanhada de uma mudança na percepção a respeito de Israel. Até pouco tempo atrás, Israel era percebido como mero país-fantoche dos interesses dos Estados Unidos no Oriente Médio. Hoje a situação se inverteu. Os Estados Unidos passaram a figurar como mero instrumento dos interesses de Israel.

A retórica do poder manipulador dos judeus aparece também em discursos de algumas lideranças políticas e religiosas de países árabese muçulmanos e circulam livremente na imprensa de tais países. Exemplo freqüentemente citado de discurso nesta direção foi proferido na $10^{\text {th }}$ Session of the Islamic Summit Conference, em 16 de outubro de 2003, por Mahathir Mohamad, ex-primeiro-ministro da Malásia. Assim se expressou, com um misto de animosidade e admiração pelos judeus, depois de condenar o uso de ataques terroristas por palestinos:

O inimigo provavelmente irá saudar essas propostas e nós concluiremos que os proponentes trabalham para o inimigo.Mas pensem. Estamosenfrentando um inimigo que pensa. Eles sobreviveram 2 mil anos de pogroms não porque revidaram, mas porque pensaram. Eles inventaram o socialismo, o comunismo, os direitos humanose a democracia para que a perseguição aeles parecesse errada e para que pudessem gozar de direitos iguais aos demais. Com isso, agora ganharamo controle do país maispoderoso, essa minúscula comunidade tornou-se um poder mundial 34 .

A retórica de confrontação e condenação política que faz uso de

[35] Esse texto apócrifo, publicado no início do século XX, descreve o plano dos judeus para dominar o mundo;é considerado um marco que inaugura a teoria da conspiração judaica.

[36]Al-Doustour (Jordânia), 17/4/ 2003. Esse extrato e o seguinte são citados em Wieviorka, op. cit.,p.112,e constam do inventário realizado pelo site www.proche-orient.info. repertório anti-semita é veiculada livremente na imprensa do Oriente Médio, mas também via internet, para o mundo todo. Nesses textos são apresentadas acusações, no velho estilo dos Protocolos dos Sábios de Sião35, nos quais os israelenses são retratados como praticantes de rituais criminosos: "As fatwas [pronunciamento legal de um líder religioso] israelenses apelam abertamente para a matança de crianças palestinas menores de onze anos, inclusive de fetos, com o objetivo de depuração étnica" 36 . A imagem segundo a qual os judeus se organiza- 
riam sob um poder central conspiratório também é comum. Resenha elogiosa de um livro de Fahti-el-Ibyari detalha o funcionamento do poder judaico: "os judeus do mundo são dirigidos por uma organização ultra-secreta chamada 'Kahila', ou cérebro diabólico, composta de trezentos diabos ou representantes de Satã" 37 . Essa instituição seria responsável pelo assassinato de sábios nucleares egípcios, pela destruição da economia mundial, pelas guerras na Ásia e na África e pelo colapso da União Soviética.

Conquanto seja possível encontrar algumas referências preconceituosas sobre os judeus no Alcorão, como por exemplo serem considerados traidores de Maomé ${ }^{38}$, a tradição islâmica não transformou os judeus concretamente mencionados no Alcorão no "eterno judeu" ou no "judeu abstrato", à semelhança da versão predominante até pouco tempo atrás no cristianismo. O Alcorão inclusive contém alguns versos que indicam relações amigáveis entre o Profeta e alguns judeus, e na tradição islâmica os judeus são vistos como membros de uma comunidade legítima de crentes em Deus, o "povo do Livro" destinado ao sofrimento. A teologia islâmica, vista desse modo, contrasta com as concepções católicas do judeu abstrato, que carrega para sempre a marca da traição de Jesus. Dessa forma, não é possível afirmar que o anti-semitismo islâmico hoje seja um produto autenticamente islâmico. E, mesmo se o compararmos aos registros preconceituosos em relação aos judeus em boa parte da história cristã, veremos certamente que o islamismo apresenta níveis de tolerância superiores.

Assim, alguns estudiosos interpretam o anti-semitismo islâmico recente como decorrência da criação do Estado de Israel e do permanente conflito entre israelenses e palestinos. Todavia, a utilização de imagens estereotipadas dos judeus para se referir ao conflito do Oriente Médio faz supor que há algo mais em jogo do que somente o sionismo e as políticas de Israel. Como sugere Kramer39, trata-se da influência do anti-semitismo religioso e racial do Ocidente sobre o proselitismo antijudaico do Oriente Médio. Tal influência foi propiciada pela circulação de elites intelectuais islâmicas nas universidades européias, elites que assimilaram a visão preconceituosa e estereotipada dos judeus e a deslocaram para o contexto do Oriente Médio. Transformada em acusação genérica aos judeus, que se estende além do anti-sionismo, os judeus passaram a ocupar o lugar dos conspiradores, semelhante àquele que ocuparam no discurso anti-semita da Europa moderna.

Segundo Wieviorka ${ }^{40}$, o novo anti-semitismo, baseado em diferentes camadas do antijudaísmo cristão e moderno, não provém daqueles que têm uma prática concreta de relação com os judeus, sejam os árabes de Israel, sejam os palestinos que vivem nos territórios ocupados. Em tais regiões, essas imagens encontram pouco espaço de repercus-
[37] Akher Saa'a (Egito), 26/o2/ 2003.

[38] O Alcorão relata que alguns judeus se comportaram como traidores do Profeta Maomé.

[39] Kramer, Martin. The salience of Islamic anti-Semitism. Institute of Jewish Affairs Reports, Londres, n. 2, out. 1995 (http://www.geocities.com /martinkramerorg/Antisemitism.htm).

[40] Wieviorka, op.cit. 
[41] Iran Focus, 11/2/2006.

[42] Jerusalem Post, 10/2/2006. são. São, sobretudo, os meios de comunicação da Jordânia, da Arábia Saudita, do Líbano e do Egito que fornecem esse fluxo de imagens preconceituosas sobre os judeus. Desse modo, encorajam os leitores a odiar Israel e os judeus em geral, o que permite, segundo o autor, a criação de uma suposta causa árabe e muçulmana comum, cujo objetivo é evitar a crítica interna aos regimes políticos vigentes.

Em meio à retórica antijudaica, é cada vez mais notável a representação dos judeus como metáfora do Ocidente. Isso pode ser ilustrado pela maneira como os judeus e Israel foram envolvidos na chamada "controvérsia das charges de Maomé", que teve início em setembro de 2005. Na impossibilidade de conseguir alguém que ilustrasse a biografia de Maomé escrita por um autor dinamarquês, o jornal Jyllands-Poste publicou charges do Profeta consideradas ofensivas ao islã, especialmente a que mostra Maomé com uma bomba no turbante. Esse incidente repercutiu rapidamente no Ocidente e ensejou um caloroso debate sobre democracia e os limites da liberdade de imprensa. Em vários países árabes e mulçumanos desencadeou-se uma onda de manifestações de rua violentas, com a ritual queima de bandeiras, inclusive a de Israel, e com apelos ao boicote de produtos dinamarqueses na região. Na seqüência dos protestos, a imprensa de muitos países árabes e muçulmanos resolveu, como retaliação à Europa, publicar caricaturas que aludiam à conspiração judaica para controlar o mundo, que debochavam do Holocausto e apresentavam imagens demoníacas e estereotipadas dos judeus (nariz grande, casaca preta, chapéu de abas largas, corpo disforme etc.), semelhantes àquelas que se tornaram habituais na imprensa anti-semita da Europa moderna.

A despeito de Israel e dos judeus não estarem na origem desse episódio, eles foram envolvidos na disputa. Aqueles que se sentiram insultados alegaram que os judeus estavam por trás do incidente. $\mathrm{O}$ presidente do Irã, Ahmadinejad, declarou na ocasião que "aqueles [que insultam o fundador do islã] são reféns dos sionistas. E os povos da Europa e dos Estados Unidos pagaram um alto preço por terem se transformado em reféns dos sionistas" 41 . O líder do Hezbollah, Sheikh Hassan Nasrallah, que encabeçou a manifestação de milhares de pessoas no Líbano, alegou que, se as vítimas do insulto fossem judeus, o Ocidente teria agido rapidamente: "É o mundo islâmico menos importante que um punhado de sionistas? Não podemos aceitarisso...Vamos levar a mensagem de Deus não apenas pela nossa voz, mas pelo nosso sangue" 42 . O que importa reter desse evento é que Israel deixou de ser uma realidade geográfica, política e nacional concreta para se transformar nos "judeus", e esses, por sua vez, em símbolo que condensa as representações negativas acerca da Europa e do Ocidente em geral. 
Outro tema que se destaca na nova retórica anti-semita consiste na negação do Holocausto e na associação de Israel aos símbolos nazistas. O Holocausto é, com certeza, o principal evento ao redor do qual a identidade judaica contemporânea se construiu, particularmente na diáspora. A conexão entre o tema do Holocausto e Israel se fortaleceu recentemente como estratégia do governo de Israel para legitimar a existência do Estado em face do crescimento do discurso anti-sionista de seus adversários.

A negação do Holocausto, que se iniciou na Europa com os chamados historiadores "negacionistas", penetrou na consciência de parcelas expressivas do islamismo radical nos últimos anos43. Mais precisamente, em um primeiro momento, mencionava-se o Holocausto não para negá-lo, mas para argumentar que a solução do problema do anti-semitismo europeu não poderia recair sobre o povo palestino. Em seguida, observa-se uma mudança na relação com o Holocausto, cuja existência é negada. Para os "negacionistas", o Estado de Israel não pode se justificar pelo Holocausto, já que nunca teria existido44. Desta forma, o "negacionismo" europeu foi assimilado pelo radicalismo islâmico como estratégia política na luta contra a existência do Estado de Israel.

Ao mesmo tempo, aparece no espaço público, com certa assiduidade, a construção simbólica de analogias entre Israel e os nazistas. Tais analogias - que certamente contradizem o discurso "negacionista", já que sua força retórica repousa justamente na associação de Israel com o "mal absoluto" - são comunicadas por meio de caricaturas ecartoons, grafites nos muros das cidades européias, em faixas ecartazes exibidos nas manifestações de rua na Palestina eem diversos países árabes e muçulmanos, bem como em passeatas realizadas pelo movimento antiglobalização45. Nesses diferentes espaços, a estrelade-davi é igualada à suástica, ou a suástica é sobreposta ao mapa de Israel e ao rosto dos seus governantes. Segundo Markovits ${ }^{46}$, a utilização dos símbolos nazistas para caracterizar Israel aspira a cumprir três objetivos: o primeiro é deslegitimá-lo, associando-o ao símbolo mais conhecido do "mal absoluto"; o segundo pretende humilhar o povo judeu, igualando-o aos perpetradores do genocídio que quase o eliminou há sessenta anos; o terceiro pretende liberar a Europa da culpa que guarda pela relação histórica tumultuada que manteve com os judeus. E, finalmente, ao imputar aos israelenses e a Israel qualidades demoníacas e inumanas, permite, em conseqüência, legitimar qualquer meio de defesa em face da ameaça que eles representariam.

Conforme sugerem os exemplos acima descritos, o discurso antisionista, principalmente aquele irradiado do Oriente Médio, tem assumido uma linguagem que aciona antigos preconceitos e estereótipos típicos da retórica anti-semita da Europa moderna.

\begin{abstract}
[43] Said, Edward W. "Réponse aux intellectuctuells árabes fascinés par Roger Garaudy. Israel-Palestine, une troisième voie". Le Monde diplomatique, ago. 1998 (http://www. mondediplomatique.fr/1998/o8/SAID/ 10786).
\end{abstract}

[44] Para um levantamento de pronunciamentos "negacionistas" na Europa e no Oriente Médio, ver www.Wikipedia.org/wiki/Holocaust_denial. O pronunciamento de maior repercussão na mídia ocidental foi proferido pelo presidente do Irã, Mahmoud Ahmadinejad, na reunião da Organization of Islamic Conference (OIC), realizada em Meca em 2005. Assim se expressou o presidente iraniano: "Alguns países europeus insistem em dizer que Hitler matou milhões de inocentes judeus em crematórios, e eles insistem nisso, e, se alguém provar qualquer coisa em contrário, eles condenam essa pessoa e a colocam na prisão". O pronunciamento foi fortemente criticado pelo Muslim Public Affairs Council, organização que trabalha em prol dos direitos civis dos americanos muçulmanos.

[45] Uma vez que o movimento antiglobalização congrega diferentes grupos, não é possível generalizar manifestações que ali ocorrem como se fossem representativas do movimento como um todo. Naomi Klein, escritora e ativista do movimento antiglobalização e severa crítica das políticas do governo israelense, manifestou sua preocupação com o fato de que "enquanto o movimento antiglobalização sempre se manifesta corretamente contra o antiislamismo, nunca se pronuncia contra a onda de anti-semitismo na Europa". E sua indignação continua: "Toda vez que eu acesso o site de livre acesso de notícias de ativistas do movimento, 
como o Indymedia.org, eu me confronto com um fio de teorias conspiratórias sobre os judeus acerca do 11 de Setembro e com citações do Protocolo dos Sábios de Sião. O movimento antiglobalização não é anti-semita, ele apenas ainda não enfrentou as implicações de mergulhar nos conflitos do Oriente Médio [...]. É possível criticar Israel e condenar vigorosamente o crescimento do anti-semitismo. E é igualmente possível ser a favor da independência da Palestina, sem adotar uma visão simplista $e$ dicotômica 'pró-Palestina/anti-Israel', imagem que espelha a equação 'o bem versus o mal', tão cara ao presidente George W. Bush" (Toronto Globe $\&$ Mail, 24/4/2002, http:// www. zmag.org/content/Activism/klein_oldhates.cfm).

[46] Markovits, Andrei S. “'Twin brothers': European anti-Semitism and anti-Americanism". Jerusalem Center for Public Affairs, Post-Holocaust and Anti-Semitism: Web Publications, n. 6, 8/1/2006 (http://www. jcpa.org/phas/phas-markovitso6.htm).

[47] Bell, Daniel A. Communitarianism and its critics. Oxford: Oxford University Press, 1993; Taylor, Charles. The ethics of authenticity. Cambridge: Harvard University Press, 2000.

[48] Taguieff, Pierre-André. La force du préjuge: essai surle racisme et ses doubles. Paris: Éditions La Decouverte, 1987.

\section{CONCLUSÕES: REPENSANDO O MULTICULTURALISMO}

A combinação peculiar da retórica anti-sionista em circulação no Oriente Médio com o repertório típico de imagens e símbolos do antisemitismo moderno europeu encontra hoje na Europa um espaço propício de reprodução naqueles setores duplamente condicionados pela identificação que mantêm com as versões mais radicais da causa palestina e pela experiência de exclusão e forte sentimento de injustiça social nas sociedades européias.

A escalada do anti-semitismo na Europa apresenta um sério desafio às expectativas mais otimistas de uma vida pública baseada em "comunidades" e de sua capacidade de promover o bem-estarcomum. Com o fim da Guerra Fria e dos regimes autoritários do bloco soviético, a retórica política no Ocidente, centrada no ideário da democracia liberal, de liberdade e direitos individuais, passou a ser percebida como ultrapassada e pouco atraente para mobilizar a participação dos cidadãos na política. Em contrapartida, as "comunidades" com suas práticas e crenças foram redescobertas na sua capacidade de oferecer uma visão mais substantiva do self,tornar a política mais rica e promover um significativo avanço do bem comum ${ }^{47}$.

Os regimes liberais, por não reconhecerem o que seencontrava fora de sua jurisdição, foram desafiados pela chamada "política das identidades", ou seja, desafiados pelas atividades de grupos e movimentos sociais que reivindicam a representação dos interesses de setores particulares da sociedade. Tais grupos compartilhariam uma experiência comum, real ou percebida, de injustiça social com relação à sociedade mais ampla da qual participam.

A "política da identidade" significa mais que o reconhecimento de identidades desfavorecidas pelos estereótipos e preconceitos dominantes. Implica levar a auto-identificação religiosa, cultural ou étnica para o centro da vida política e institucional. O espaço público, assim redefinido, seria, então, o locus da co-habitação das diferenças e suas correspondentes narrativas. Os seus defensores, em geral, só concebem como hipótese negativa desse modelo a emergência de uma indiferença relativista entre as culturas, de modo que a hipótese de conflito entre "comunidades" em um contexto multicultural é em geral ignorada. Todavia, as "culturas", "etnicidades" e "religiões" não são necessariamente virtuosas e, muito freqüentemente, são apropriadas por lideranças políticas e religiosas que constroem identificações imaginárias, segundo as quais aos indivíduos são designadas categorias fixas e presumivelmente autênticas de pertencimento. Inversamente, a identidade coletiva, como classe de pertencimento, passaria a ser a única a plasmar a qualidade de um verdadeiro indivíduo, isto é, um ser único, singular e indivisível ${ }^{48}$. 
Esse jogo de identidades produz, desse modo, a indiferenciação dos indivíduos: cada ação pessoal é percebida como expressão de uma coletividade. Especificamente, no caso de que estamos tratando, essa construção supõe que ações condenáveis do governo de Israel sejam responsabilidade da entidade "povo judeu", ou que uma charge de um humorista dinamarquês, percebida como ofensiva, incrimina o "Ocidente", que, por sua vez, é simbolizado pelos "judeus". Na mesma chave de interpretação, um ato terrorista é considerado culpa do "islã", ou um ato de agressão de um jovem descendente de imigrantes é um crime cometido por "árabes". Assim, sucessivamente, pessoas são categorizadas em termos da suposta tradição, religião ou cultura que herdaram da sua comunidade de origem.

Klug ${ }^{49}$, através de um experimento teórico, nos convida para uma reflexão a respeito das vivências imaginárias de um certo rabino idoso que fora retirado do ônibus $73 \mathrm{em}$ Londres pela motorista Mary. $\mathrm{Na}$ calçada, o rabino Cohen reflete se foi vítima de anti-semitismo. Em outras palavras, será que ele experimentou a hostilidade básica que se manifesta contra o judeu como o "judeu"? E se o rabino Cohen estivesse fumando no ônibus? Mesmo que a longa barba e o solidéu obviamente o identificassem como judeu, talvez Mary simplesmente o tivesse colocado para fora do ônibus porque ele estava fumando no interior do veículo. Dessa maneira, Mary não lhe teria dispensado um tratamento diferente ao dado a Jane Smith ou a Bhupinda Singh, também retirados do ônibus naquele mesmo dia. Se é assim, a decisão decorreu do fato de ele ser fumante, e não de ser judeu. E se Mary tivesse retirado o rabino do ônibus por ele cantar uma música religiosa, profundamente importante para ele como judeu, no máximo da sua voz? Será que ela o teria expulsado porque ele cantava ou porque cantava uma música judaica? Teria sido porque cantava como judeu ou porque cantava alto? Foi ele retirado do ônibus por ser judeu ou por ser barulhento? E se Mary foi, de fato, preconceituosa e intolerante na sua atitude com o rabino Cohen? Ela conhece esse tipo de pessoa e decidiu pô-lo ostensivamente para fora do ônibus não porque estava cantando, mas porque, na verdade, ele é um estrangeiro criador de caso que, para começo de conversa, nem deveria estar ali. Basta olhar para o rabino Cohen, com sua aparência oriental, sua longa barba e seu boné esquisito, para confirmar a Mary exatamente o que ele é: um desses mullahs. "Cai fora, Abdul", grita ela enquanto o empurra para a calçada, onde o rabino Cohen reflete, filosoficamente, se não teria sido uma vítima da islamofobia!

Islamofobia, racismo, xenofobia e anti-semitismo guardam a mesma estrutura elementar de classificação, apesar dos diferentes temas selecionados pelos seus respectivos discursos. Nela, as individualidades são dissolvidas em nome do conforto que a divisão totali-
[49] Klug, Brian. "The collective Jew: Israel and the new anti-Semitism", Patterns of Prejudice (Londres: Routledge), vol. 37, n. 2, jun. 2003, apud Slim, Hugo. How we look: hostile perceptions of humanitarian action, 2004 (http://www.hdcentre.org). 
Recebido para publicação

em 30 de março de 2007.

\section{NOVOSESTUDOS}

CEBRAP

79 , novembro 2007

pp. 97-115 tária entre o "nós" e o "eles" confere aos habitantes de sociedades em constante mudança. Nesse sentido, a forte demanda por reconhecimento das identidades como meio para a promoção do bem comum não é evidente. É é sobre esse novo paradigma de organização política que a Europa Ocidental se debate atualmente.

BILA SORJ é professora titular de sociologia da Universidade Federal do Rio de Janeiro (UFRJ).É autora de Identidadesjudaicas no Brasil contemporâneo (Imago, 1997), e co-autora, junto com Guila Flint, de Israel, terra em transe. Democracia ou teocracia? (Civilização Brasileira, 2000). 